\title{
Psychological Consequences of Professional Activity of Oncologists in Coronavirus Pandemic Conditions
}

\author{
Evstifeeva E.A. ${ }^{1}$ Filippchenkova S.I. ${ }^{1,{ }^{*}}$ Murashova L.A. ${ }^{2}$ \\ ${ }^{1}$ Tver State Technical University, Tver, Russia \\ ${ }^{2}$ Tver State Medical University, Tver, Russia \\ *Corresponding author. Email: sfilippchenkova@mail.ru
}

\begin{abstract}
Medical and psychological studies conducted by the authors in the midst of the first wave of coronavirus pandemic (June 2020) to identify psychological consequences in the professional activities of oncologists in the context of coronavirus pandemic showed the following. In a situation of professional tension, in the uncertain and unpredictable conditions of medical outcomes, additional risks arise for the psychological and professional health of the doctor. There is a psychological "depletion" of that professional resource of a doctor, which directly affects the doctoring process effects. The critical research findings on such descriptors as burnout and communicative tendencies point to a problem of divergence with the principle of participation in personalized medicine. According to the results of the study, two-thirds of the examined oncologists have an explicated burnout syndrome and a low level of communicative components in communicating with cancer patients.
\end{abstract}

Keywords: pandemic, personalized medicine, oncologist, burnout, communication tendencies

\section{INTRODUCTION}

The coranavirus (Covid-19) pandemic is not just a medical problem. People call the pandemic a drama staged and performed by humanity. Biological, psychological, political, and economic, cultural, and symbolical, metaphysical discourses are facing it today. They emphasize that the virus (Covid-19) with its poly hybrid characteristic is a challenge of the wild nature, an existential challenge to humans, the ultimate experience of mankind, self-test, a "survival game", a blow to global politics and economics $[1,5]$.

The pandemic appeared as a severe crisis for social life and humanity in general, showing the exaggeration of our somatic life, corporeality on the part of the mind. It negatively affects the physical, mental, psychological health of most people in the world, worsens their objective and subjective well-being $[9,10,14]$. Medical workers are at a higher risk from the consequences of the virus and in the context of preserving health. Besides the general situation - self-isolation, quarantine, which lower the previous standard of living in terms of such parameters as safety, anxiety and fear, stress, it adds such professional risks as the risk of infection, increased work intensity, physical and mental fatigue, social isolation, separation from loved ones, etc. [3]. For doctors, their professional competencies are faced with the latest cognitive situation uncertainty, unpredictability of a viral disease, and its impact on other pathologies, as well as methods, technologies, and outcomes in treating activity $[4,12]$.

This epidemic has revealed its unfavorable consequences for the psychological and professional health of Russian doctors. Even the scarce world literature on the consequences of the "Covid-19 Virus" phenomenon confirms this situation [6]. In conditions of social restriction, emotional problems such as overwhelming anxiety, pronounced fear of getting sick and dying, depressed mood, helplessness in a continuum with existential experiences of melancholy, loneliness, depression, and despair were most acutely revealed. Negative emotions initiated by isolation, cessation of public services, financial losses, confusion of scientific medicine regarding the forecasts of morbidity, and its consequences could not but affect the professional activities of doctors.

The extreme level of neuropsychic tension and a powerful stress factor, the maximum duration of the working day with the expenditure of physical and mental resources, disruption of the usual work rhythm, quarantine conditions, a high risk of infection with a threat to life, lack of protective equipment resulted in a syndrome of rapid emotional burnout, which manifests itself for easing the professional duties, emotional and personal alienation of doctors. It is also accompanied by a violation of the productivity of communication between a doctor and a cancer patient, which constitutes the principle of participation in personalized medicine, as an accepted newest concept in Russian healthcare. 


\section{METHODOLOGY}

This article is a fragment of the research and development project called "Health-related quality of life management in oncology: interdisciplinary approaches, existential and psychological model of treatment." An existential and psychological model of treatment is being developed by the authors in accordance with the concept of personalized medicine (PM), which is being introduced in the world and national healthcare $[7,13]$. Personalized medicine is the newest organization of medical care for the population, as well as the latest technological model of treatment, which includes stratification parameters and personalized data of a person, which entails the selection of individual diagnostic, therapeutic and preventive tools. Presented as an interdisciplinary project, personalized medicine is focused on postnonclassical scientific rationality, constructivist approach, modeling, interdisciplinary research methods, the convergence of medical, psychological, and other experiences.

At its core, the existential and psychological model of treatment is a convergent model that integrates the medical and psychological components of the treatment process. The existential and psychological model of treatment is explicated as a psychometric toolkit for describing, explaining, generalizing the results of the study of medical, psychological, existential, and semantic measurements of the doctor's figure and the figure of the cancer patient. On the one hand, such construction is focused, on the development and improvement of professional activity, personal and subjective qualities of a doctor, and on the other hand, on the personal parameters of QOL related to the health of an oncological patient, his existential attitude, reflexive stance and responsibility concerning his illness, and their broadcast on the "quality of life" indicators.

In such a crisis situation as oncopathology, according to the existential approach, subjective well-being or "existential fulfillment" of a person's life can be identified. We are talking about the so-called subjective truth, where truth is nothing more than a value-based epistemological attitude to a life situation, fate, illness, etc. "One's" truth always affects the freedom of decision-making for any situation. As we prove with our research, the use of a package of psychodiagnostic techniques with the methodology of health-related quality of life allows achieving a generalized indicator of objective and subjective well-being. We provide a rationale for why the objective and subjective indicators of health-related quality of life change under the influence of the psychological characteristics of the cancer patient. Among them are existential mood, reflexivity, responsibility as a locus of control, trust, communication skills.

According to the basic principle of PM participation, communication between a doctor and a patient is built as a dialogue and a high degree of trust in the decision-making process on the oncopathology treatment strategy and tactics. Participation appeals to the developed communicative skills of the doctor, which entails a synergetic effect on the disclosure and activation of the subjective personal and psychological factor of a cancer patient. Developed professionally important qualities of a doctor (professional identity, responsibility, trust in oneself and others, reflexivity, emotional stability, communication skills, emotional intelligence, existential fulfillment, meaningful life orientations), which are measured in our research project, significantly affect the success of treatment, which verified by indicators of health-related quality of life [11].

\section{RESULTS}

Medical and psychological studies conducted by us in the midst of the first wave of coronavirus pandemic (June 2020) to identify psychological consequences in the professional activities of oncologists in the context of coronavirus pandemic showed the following. There is a psychological "depletion" of those professional, personal, and subjective resources of the doctor that directly affects the doctoring process effects. The respondents of the study were doctors and heads of departments of the Tver Regional Clinical Oncological Dispensary, the faculty of the Department of Oncology, Surgery and Palliative Medicine of the TSMU (45 people, of which 24 men and 21 women aged 34 to 73 years, average age 47,08 \pm 9.5 ). The following psychodiagnostic tools were used: V.V. Boyko's technique to study the level of emotional burnout (modified by E. Ilyina) [2]; diagnostics technique of communicative and organizational inclinations (KOS-2) Fetiskina N.P. (analysis of the communicative potential of medical workers) [8]. The SPSSStatistics 22 software package was used for statistical analysis.

On the fact of the conducted research of emotional burnout according to the V.V. Boyko's technique, the following data on the formation of symptoms of emotional burnout was obtained, which include the following scales: selfdoubt, being caged, reduction of professional duties, emotional detachment, personal detachment (depersonalization). The results showed that the "Selfdissatisfaction" symptom was not formed in $57 \%$ of the respondents, is in the stage of a developing symptom in $7 \%$, and is developed in $36 \%$. "Caged" symptom is not formed in $42 \%$ of doctors, is in the stage of a developing symptom in $13 \%$, is developed in $45 \%$. The "Reduction of professional duties" symptom is not formed in $24 \%$ of doctors, is in the stage of a developing symptom in $40 \%$, and is developed in $36 \%$. The "Emotional detachment" symptom is not formed in $24 \%$ of doctors, is in the stage of a developing symptom in $40 \%$, and is developed in $36 \%$. The "Personal detachment (depersonalization)" symptom was not formed in $37 \%$ of doctors, is in the stage of a developing symptom in $24 \%$, and is developed in $39 \%$.

According to descriptive statistics, the average indicator of self-dissatisfaction among oncologists was $12.0 \pm 6.8$ points; being caged $-12.5 \pm 10.3$; reduction of professional duties - 13.7 \pm 8.6 ; emotional detachment - 16.2 \pm 6.0 ; personal detachment - 13.0 \pm 9.6 (Table 1). 
Table 1: Indicators of the symptoms formation of emotional burnout in oncologists

\begin{tabular}{|c|c|c|c|c|c|}
\hline Symptoms & $\mathbf{N}$ & Minimum & Maximum & $\begin{array}{c}\text { Average } \\
\text { value }\end{array}$ & $\begin{array}{c}\text { Standard } \\
\text { deviation }\end{array}$ \\
\hline Self-dissatisfaction & 45 & 3.00 & 24.00 & 12.0 & 6.8 \\
\hline Being caged & 45 & 2.00 & 28.00 & 12.5 & 10.3 \\
\hline $\begin{array}{c}\text { Reduction of } \\
\text { professional duties }\end{array}$ & 45 & 2.00 & 28.00 & 13,7 & 8.6 \\
\hline Emotional detachment & 45 & 6.00 & 28.00 & 16.2 & 6.0 \\
\hline Personal detachment & 45 & 2.00 & 30.00 & 13.0 & 9.6 \\
\hline $\begin{array}{c}\text { N valid (according to } \\
\text { the list) }\end{array}$ & 45 & & & & \\
\hline
\end{tabular}

The use of the N.P. Fetiskin diagnostic technique for communicative and organizational inclinations (KOS-2), which is intended for psychological diagnostics of the communicative potential of medical workers, indicated a low level of communicative inclinations (Fig. 1) in $34 \%$ of respondents, the below-average level - in $40 \%$, the average level - in 20\%, the high level was not detected in any person and a very high level in 6\%. A low level organizational skills in $72 \%$ of respondents, below average - in $18 \%$, average - $0 \%$, high - in $4 \%$, very high - in $6 \%$.

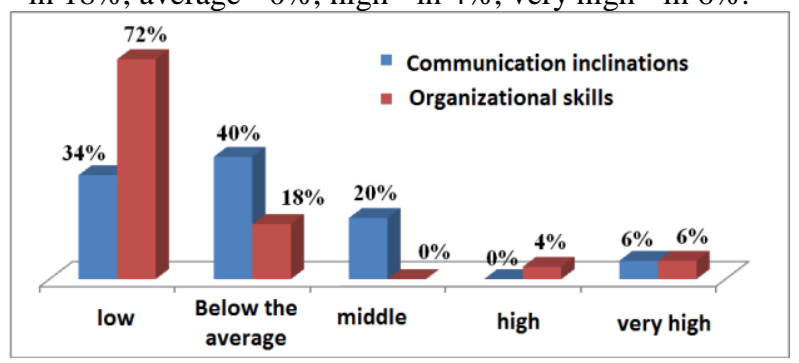

Figure 1: Level of communication and organizational skills among oncologists

According to descriptive statistics (Table 2), the average indicator of communication skills was $0.51 \pm 0.12$ points and internality $0.50 \pm 0.15$ points.

Table 2: Indicators of the average group indicators of communicative inclinations and organizational skills among oncologists

\begin{tabular}{|l|l|l|l|l|l|}
\hline & $\mathbf{N}$ & Minimum & Maximum & $\begin{array}{l}\text { Average } \\
\text { value }\end{array}$ & $\begin{array}{l}\text { Standard } \\
\text { deviation }\end{array}$ \\
\hline $\mathrm{KS}$ & 45 &, 30 &, 80 &, 5167 &, 12925 \\
\hline $\mathrm{OU}$ & 45 &, 15 &, 85 &, 5073 &, 15655 \\
\hline
\end{tabular}

\section{DISCUSSION OF FINDINGS}

According to the results of the study, two-thirds of the respondents have a developed emotional burnout syndrome as an indicator of a negative psycho-emotional state, destabilizing the communicative interactions of a doctor at the workplace and interfering with the effectiveness of the implementation of therapeutic and preventive processes in a medical institution. This situation is accompanied by self-dissatisfaction, low selfesteem, lack of confidence in oneself and in one's own strength, inability to adequately assess the results of one's work, and correlate one's successes with abilities and level of professionalism. The high value of this indicator reflects a tendency towards a negative assessment of one's professional competence and productivity, as well as a decrease in professional motivation. The oncologist feels as if constrained, intimidated, immersed in a routine, underestimated by patients, and especially colleagues, which leads to a state of despair, which appears as higher mental stress, catastrophically low job satisfaction, the emergence of a vicious circle of low self-esteem. And if the mechanisms of psychological defense are triggered, the person experiences a state of intellectual and emotional congestion, a dead end. Minimization and formalization of professional work leads to an increase in negative feelings in relation to professional activity. The intention of the doctor is not to get involved in the work process, but to transfer and shift his duties and responsibilities to the surrounding colleagues, or to the nursing staff. This is accompanied by an attitude towards self-isolation from the professional field and colleagues, towards avoiding and evading the work situation. Further, according to the results of psychodiagnostic research, the overwhelming majority of our respondents, objectified as subjects, do not have the abilities and competencies of productive communication, they feel limited in new communication, in a team; narrow the circle of communication to "selfcommunication"; have complexes when establishing contacts with people and when speaking to an audience; are disoriented in a new, unknown situation; do not claim their own opinions, are hard at grievances; the manifestation of initiative in social activity is practically reduced, in many actions where decisions need to be made, they prefer not to make decisions on their own

\section{CONCLUSION}

The results obtained in the course of our studies confirm that the act of communication between a doctor and a cancer patient is complicated by the presence of a low level of communicative and organizational inclinations of doctors. Such results can be caused and explained by the presence of emotional burnout syndrome among doctors. Our studies during the COVID-19 epidemic have explicated the presence of critical indicators of the psychological health of doctors. Such obligate descriptors as emotional burnout and undeveloped communicative inclinations in the professional activity of doctors do not coordinate with the implementation of the principle of participation in personalized medicine. Obviously, the context of the professional activities of doctors became more complicated during the pandemic, taken as the negative impact of restrictive measures, self-isolation, contradictive and fake information. This could not but affect their psychological and professional health. The tense situation provoked such pronounced problems as dissatisfaction with their activities, simplification of professional duties, emotional and personal alienation. There is an urgent need to develop a system of psychological support for oncologists, including 
psychological trainings, group and individual counseling on problems in their professional activities.

\section{ACKNOWLEDGMENT}

The study was carried out with the financial support of the Russian Foundation for Basic Research within the framework of the scientific project No. 19-013-00038 called "Management of health-related quality of life in oncology: interdisciplinary approaches, existential and psychological model of treatment" (2019-2021).

\section{REFERENCES}

[1] Agamben Dzh. Otkrytoye: Chelovek i zhivotnoye / per. s ital. i nem. B.M. Skuratova pod red. M.

Mayatskogo i D. Novikova. M.: RGGU, 2012;

[2] Boyko V.V. Sindrom emotsional'nogo vygoraniya v professional'nom obshchenii. $\mathrm{SPb}, 2009.278 \mathrm{~s}$.

[3] Krom I.L, Yerugina M.V., Yeremina M.G., Kovalev Ye.P., Ye.M. Dolgova Ye.M, Bochkarova G.N., Grigor'yeva Ye.G. Riski zdorov'yu professional'noy gruppy vrachey v sovremennykh sistemakh zdravookhraneniya (obzor) // Analiz riska zdorov'yu. 2020. - № 2. - S. 185-DOI:

10.21668/health.risk/2020.2.20

[4] Lubenitskaya A.N., Ivanova T.I. Mir uzhe nikogda ne stanet prezhnim - pandemiya novogo tysyacheletiya (Obzor literatury). Omskiy psikhiatricheskiy zhurnal. 2020; 2-1S (24): 16-22. doi: 10.24411/2412-88052020-10203

[5] Markov B.V., Sergeyev A.M., Bocharnikov V.N. Fenomen pandemii skvoz' prizmu metafizicheskogo, antropologicheskogo i sotsial'nogo izmereniy // Chelovek. 2020. T. 31, № 3. S. 7-24. DOI: $10.31857 / \mathrm{S} 023620070010034-4$.

[6] Ostrovskiy D.I., Ivanova T.I. Vliyaniye novoy koronavirusnoy infektsii COVID-19 na psikhicheskoye zdorov'ye cheloveka (Obzor literatury). Omskiy psikhiatricheskiy zhurnal. 2020; 2-1S (24): 4-10. doi:10.24411/2412-8805-2020-10201

[7] Rodionov, Ye.O. Personalizirovannyy podkhod k posleoperatsionnoy khimioterapii v kombinirovannom lechenii nemelkokletochnogo raka legkogo (klinicheskoye nablyudeniye) / Ye. O. Rodionov Tekst : neposredstvennyy // Sibirskiy onkologicheskiy zhurnal. - 2016. - № 3. Tom 15. - S. 97-101.
[8] Fetiskin, N.P. Sotsial'no-psikhologicheskaya diagnostika razvitiya lichnosti i malykh grupp : uchebnoye posobiye / N.P. Fetiskin, V.V. Kozlov, G.M. Manuylov. - 2-ye izdaniye, dopolnennoye. - Moskva : Psikhoterapiya, 2009. - 544 s. - ISBN 978-5-90318245-9

[9] Brooks SK, Webster RK, Smith LE, Woodland L, Wessely S, Greenberg N,et al. The psychological impact of quarantine and how to reduce it: rapidreview of the evidence. Lancet. 2020;395:912-20;

[10] Dong, L., Bouey, J., 2020. Public mental health crisis during COVID-19 pandemic, China.Emerg. Infect. Dis. 23 (26).

[11] Filippchenkova S.I., Evstifeeva E.A. and Murashva L.A. Hermeneutics of concepts of the existential-psychological healing model // SHS Web Conf. Volume 69, 2019 The International Scientific and Practical Conference "Current Issues of Linguistics and Didactics: The Interdisciplinary Approach in Humanities and Social Sciences" (CILDIAH-2019) https://www.shs-

conferences.org/articles/shsconf/abs/2019/10/shsconf_c ildiah2019_00041/shsconf_cildiah2019_00041.html

[12] Montemurro N., 2020. The emotional impact of COVID-19: From medical staff to common people. Brain, behavior, and immunity, 2020. P. 1-2. https://doi.org/10.1016/j.bbi.2020.03.032.

[13] PPPM (Predictive, Preventive and Personalized Medicine) as a new model of national and international healthcare service and thus a promising strategy to prevent a disease: from basics to practice / I.A. Sadkovsky [et al.] // International Journal of Clinical Medicine. -2014.№ 5. P.855-870).

[14] Shigemura J, Ursano RJ, Morganstein JC, Kurosawa M, Benedek DM.Public responses to the novel 2019 coronavirus (2019-nCoV) in Japan:mental health consequences and target populations. Psychiatry Clin Neurosci. 2020;74:281-282 